\title{
Molecular Identification of Phytophthora palmivora in the Cocoa Tree Orchard of Côte d'Ivoire and Assessment of the Quantitative Component of Pathogenicity
}

\author{
K. Coulibaly ${ }^{1}$, R. A. Aka1, B. Camara ${ }^{2}$, E. Kassin ${ }^{1}$, K. Kouakou1, \\ B. I. Kébé1, N. K. Koffi', M. G. Tahi' ${ }^{1}$, N. P. Walet ${ }^{1}$, S. B. Guiraud ${ }^{1}$, M. \\ E. Assi ${ }^{1}$, B. Kone ${ }^{1}$, K. F. N'Guessan¹, D. Koné2
}

${ }^{1}$ Centre National de Recherche Agronomique (CNRA), Côte d'Ivoire. Station de Recherche de Divo/Côte d'Ivoire, BP 808, Tel. /Fax: (225) 32760835

${ }^{2}$ Laboratoire de pathologie et de Physiologie végétale, UFR Biosciences, Université Félix Houphouët-Boigny de Cocody, Côte d'Ivoire

*Identification moléculaire de Phytophthora palmivora du verger cacaoyer de Côte d'Ivoire et évaluation de la composante quantitative du pouvoir pathogène

\begin{abstract}
Black pod rot is one of the most widespread diseases in the species Theobroma cacao L. In Côte d'Ivoire, it causes significant yield losses, estimated at about 10 to $60 \%$ depending on the ecological zones. This study was conducted in order to identify Phytophthora spp isolates in the cocoa orchard by the analysis of their molecular features and assess their pathogenicity on cocoa tree leaf disks having different sensitivity. Thirty-six isolates of Phytophthora spp., from 06 producing regions (Divo, Soubré, Daloa, Duékoué, Abengourou and Aboisso) were taken from immature pods naturally affected by black pod rot. Methods of molecular analysis based on PCR-RFLP techniques, sequencing the ITS1 region of ribosomal DNA and artificial inoculation tests on cocoa tree leaf disks were used to identify Phytophthora isolates and assess their aggressiveness. The results obtained enabled to identify Phytophthora palmivora and showed a difference of aggressiveness between isolates of this species with average grades of foliar sensitivity ranging from 0.90 to 3.93 .
\end{abstract}

Keywords: Aggressiveness, Black Pod Rot, ITS-RFLP, Restriction Enzyme, Theobroma cacao

\begin{abstract}
Résumé
La pourriture brune des cabosses est l'une des maladies les plus répandues chez l'espèce Theobroma cacao L. En Côte d'Ivoire, elle occasionne des pertes de production importantes, estimées à près de 10 à $60 \%$ selon les zones écologiques. Cette étude a été réalisée en vue d'identifier les isolats de Phytophthora spp., du verger cacaoyers par l'analyse de leurs caractères moléculaires et d'évaluer leur pouvoir pathogène sur disques de feuilles de cacaoyers de sensibilité différente. Trente-six isolats de Phytophthora spp., provenant de 06 régions de production (Divo, Soubré, Daloa, Duékoué, Abengourou et Aboisso) ont été prélevées sur des cabosses immatures naturellement atteintes de pourriture brune. Les méthodes d'analyses moléculaires basées sur les techniques PCR-RFLP, de séquençage de la région ITS1 de
\end{abstract}

l'ADN ribosomal et les tests d'inoculation artificielle sur disques de feuilles de cacaoyers ont servi à identifier les isolats de Phytophthora et à évaluer leur agressivité. Les résultats obtenus ont permis d'identifier Phytophthora palmivora et ont montré une différence d'agressivité entre les isolats de cette espèce avec des notes moyennes de sensibilité foliaire variant de 0,90 à 3,93 .

\section{Introduction}

Black pod rot, caused by different species of Phytophthora is one of the most economically important diseases of cocoa tree (Theobroma cacao L.). Production losses worldwide are estimated at nearly $30 \%$ (20). Côte d'Ivoire, the world's largest cocoa producer with more than $44 \%$ of the supply, is not exempt from such disease (26). Two species, Phytophthora. palmivora and P. megakarya, are the

This article is published under the terms of the Creative Commons Attribution License 4.0

Author(s) retain the copyright of this article. Publication rights with Alkhaer Publications.

Published at: http://www.ijsciences.com/pub/issue/2018-08/

DOI: 10.18483/ijSci.1707; Online ISSN: 2305-3925; Print ISSN: 2410-4477 
most significant in Africa. The first one, P. palmivora is the most ubiquitous. It is rife in many cocoa producing countries, causing losses of about 20 to $30 \%$ (11). The second one, P. megakarya endemic in Central and West Africa, is the most aggressive species. This pathogen may, in some countries, cause the loss of the entire cocoa yield (9). Indeed, in the areas where it is present attack rates by $50 \%$ are commonly observed every year; with losses that may reach $80 \%$ when the environmental conditions are much favorable for disease development (16). To fight effectively against this disease, several means were used. Generally, the control strategy adopted against black pod integrates agronomic measures sometimes used alone or in combination with chemical and genetic control. Many studies on chemical control showed that a decrease in the workload is possible with the implementation of a response protocol of four fungicide applications per year (6), (15), but such technique is restricting and generally unprofitable; moreover, such method does not fit into a sustainable process of cocoa management because despite fungicide application every rainy season to control the disease, epidemics regularly break out in each growing season. The genetic control which consists in seeking resistant or tolerant varieties to the disease, is the only one that enables to fight efficiently against its long-term progress. But the variability in the behavior of cultivars deemed resistant from one cocoa growing area to another (3) is an indication of the insufficient knowledge of pathogens as well as host-parasite interactions. The identification of Phytophthora spp. species was based historically on morphological, cytological and biochemical features (2), (5). However, although such methods are easily achievable, the assessment of morphological features is based on average values. Many overlap, due to differences in measurement of those morphological features may lead to misidentifications or inaccurate identifications. Moreover, the majority of morphological features vary depending on the environments and culture media used. Advances in molecular biology have facilitated the development of investigation techniques of fungal genomes. The information generated by molecular tools such as RFLP profiles, specific or random amplification techniques, DNA sequencing have solved several taxonomic problems. The analysis of the gene sequences of nuclear rDNA and specifically ITS regions, in order to assess intraspecific and interspecific variability of several fungal genera is a good example. In light of the issues raised by black pod caused by Phytophthora, the fight against this disease represents a major challenge for the Ivorian cocoa cultivation. This study aims at identifying Phytophthora spp, isolates in the cocoa orchard from the analysis of their molecular features and to assess their pathogenicity on cocoa tree leaf disks having variable sensitivity.

\section{Material and methods \\ Plant Material}

Three cocoa tree clones having variable sensitivity with respect to black pod were chosen. They included a sensitive clone (NA32), a moderately resistant clone (PA150), and a resistant clone (SCA6), (23). These clones stemmed from block $\mathrm{HO} 3$ of the experimental plot of the CNRA research station in Divo. Healthy leaves were taken from semi-hardened branches located in the canopy of each tree in partial shade, from 6 trees per clone that is, 12 leaves per tree. A total of 216 leaves were collected that is, 72 leaves per clone. Using a sterile punch leaf discs of $15 \mathrm{~mm}$ in diameter were taken from each leave.

\begin{abstract}
Methods
Isolation and culture of Phytophthora spp isolates. Thirty-six (36) Phytophthora spp. isolates were used for study of aggressiveness. These isolates were obtained following a systematic collection organized as a phytosanitary survey in the 6 main cocoa producing areas of Côte d'Ivoire (Divo, Soubré, Daloa, Duékoué, Abengourou and Aboisso). In each region, the collection was carried out in 10 plantations and 3 pods naturally affected by black pod were taken from each plot. The isolates were isolated on immature pods naturally affected by black pod which necrosis were under development. The pods were cleaned with $95 \%$ alcohol and flamed out for 30 seconds. After selecting the sampling area, the superficial tissues of pods were stripped using a sterile scalpel. Three cubic fragments of $7 \mathrm{~mm}$ square were collected from the subcortical tissue with a sterile punch at the necrosis growth front. Pod disks were then deposited in water agar culture medium at $1.5 \%$ in $90 \mathrm{~mm}$-diameter Petri dishes. The incubation was performed in darkness in an oven at $26^{\circ} \mathrm{C}$ for 7 days. After a week of incubation, the mycelial strands taken from the growth front were deposited onto pea agar medium contained in Petri dishes. The purification of isolates was done by successive subculture using pea agar medium.
\end{abstract}

\section{Cloning of Phytophthora spp, isolates by monozoospore isolations}

Monosporic isolates were obtained from cultures masses by monozoospore isolation following the Babacauh (3) and Ortiz-Garcia (19) techniques. Isolates were grown on pea medium in Roux flasks. Incubation was carried out in total darkness at $26{ }^{\circ} \mathrm{C}$ for 5 days and Roux flasks were then exposed to a photoperiod of 12 hours for 5 days to induce the formation of sporocysts. In order to induce the release of zoospores by mature sporocysts, the cultures were flooded each with $40 \mathrm{ml}$ of sterile 
distilled water and placed in a refrigerator $\left(4^{\circ} \mathrm{C}\right)$ for 15 minutes. They were then returned to the light of an incandescent lamp (60W) for 45 minutes at laboratory room temperature $\left(26^{\circ} \mathrm{C}\right)$. The zoospore suspension obtained in the Roux flasks was counted with a Malassez cell. The concentration of 50 to 60 zoospores $\mathrm{ml}^{-1}$ was obtained by successive dilution of an aliquot portion in which zoospores were immobilized by two drops of $10 \%$ hydrochloric acid. One hundred microliters of the calibrated suspension were spread on water agar medium at $1.5 \%$ with a bent glass rod, previously flamed and cooled in sterile distilled water. Incubation was performed in darkness at $26{ }^{\circ} \mathrm{C}$ for 12 to 24 hours. After incubation, the germinated zoospores were collected individually under binocular magnifying glass with a sterile micro lancet needle then seeded in carrot agar culture medium at a rate of 4 mono zoospores per isolate. Similarly, the mother isolate was seeded under the same conditions. After 7 days of incubation in darkness at $26{ }^{\circ} \mathrm{C}$, the son facies identical to parental facies were selected for further studies.

\section{DNA extraction}

The isolates of Phytophthora spp. were seeded on a clarified V8 medium (500 ml V8 juice, $7.5 \mathrm{~g} \mathrm{CaCO}_{2}$, 37.5 g agar-agar, $2500 \mathrm{ml} \mathrm{H}_{2} \mathrm{O}$ ) contained in $90 \mathrm{~mm}$ diameter Petri dishes. This agar medium had previously been covered with a sterile cellophane disk. Plates were incubated in darkness in an oven at $26^{\circ} \mathrm{C}$. After 7 days, the mycelium of each isolate was harvested by scraping the cellophane sheet with a sterile spatula. The mycelium obtained $(20 \mathrm{mg})$ was transferred into sterile $2 \mathrm{ml}$ Eppendorf microtubes. DNA Extraction was performed using a New Glucanex solution $\left(18 \mathrm{ml} \mathrm{H}_{2} \mathrm{O}, 42 \mathrm{ml} \mathrm{NaCl}\right.$ at $1 \mathrm{M}$, $1.8 \mathrm{~g}$ New glucanex); adjusted to $\mathrm{pH} 6$ with a solution of $5 \mathrm{M} \mathrm{NaOHThe} \mathrm{incubation} \mathrm{took} \mathrm{place} \mathrm{in}$ laboratory room temperature for 2 hours. Precipitation was conducted in $600 \mu \mathrm{l}$ of isopropanol followed by 7 -minute centrifugation. The resulting precipitates were washed with $70 \%$ ethanol and the DNA pellet was taken up in $100 \mu$ l of extraction buffer and then incubated in a water bath at $60{ }^{\circ} \mathrm{C}$ for 5 to 10 minutes for complete dissolution. The DNA concentration was assessed by agarose gel at $0.8 \%$ (2 $\mu \mathrm{l}$ DNA $2 \mu \mathrm{l}$ bromophenol blue at $1 \%$ and $9 \mu \mathrm{l}$ sterile $\mathrm{H}_{2} \mathrm{O}$ ).

DNA amplification by PCR and digestion of the ITS region using restriction enzymes

The polymerase chain reaction (PCR) of the ITS region of DNA extracts was performed with the nucleotide sequences of primers ITS1 (5'TCCGTAGGTGAACCTGCGG-3') and ITS4 (5'TCCTCCGCTTATTGATATGC-3') as described by White et al. (27). The DNA amplification reaction was performed in a Thermo Scientific Savant DNA 120-type thermocycler. It enabled to amplify by 30 successive cycles $2 \mu \mathrm{l}$ of DNA in a reaction volume of $10 \mu \mathrm{l}$ composed of $5.05 \mu \mathrm{l}$ of deionized water, $1 \mu \mathrm{l}$ of PCR buffer, $0.8 \mu \mathrm{l}$ of DNTP at $5 \mathrm{mM}$ each, $0.3 \mu \mathrm{l}$ of $\mathrm{Mgcl}_{2}$ at $25 \mathrm{mM}, 0.4 \mu \mathrm{l}$ at $20 \mathrm{pmol}$ each of primers ITS1 and ITS4, $0.05 \mu \mathrm{l} \mathrm{Taq} \mathrm{polymerase} \mathrm{at} 0.5$ unit and a drop of mineral oil (SIGMA) was deposited on top of each reaction mixture before the amplification cycle. The amplification cycle parameters used were an initial denaturation at $94{ }^{\circ} \mathrm{C}$ for $5 \mathrm{~min}$ followed by 30 cycles of denaturation at $94{ }^{\circ} \mathrm{C}$ for $1 \mathrm{~min}$, an hybridization at $55{ }^{\circ} \mathrm{C}$ for 45 seconds and an elongation at $72{ }^{\circ} \mathrm{C}$ for $2 \mathrm{~min}$. At the end, a final elongation at $72{ }^{\circ} \mathrm{C}$ for 6 minutes was carried out. The PCR products were then digested with five restriction enzymes (AluI, PvuII; HaeIII, HinfI and $M s p I)$. The digestion with restriction enzymes was performed in a total volume of $25 \mu$ composed of 11 $\mu \mathrm{l}$ of sterile deionized water, $3 \mu \mathrm{l}$ of $10 \mathrm{X}$ buffer supplied with the enzyme, $1 \mu \mathrm{l}$ of enzyme and $10 \mu \mathrm{l}$ of PCR product. The reaction medium in sterile Eppendorf microtubes was incubated in a water bath at $37{ }^{\circ} \mathrm{C}$ overnight. The digestion products were separated by electrophoresis on $1.4 \%$ agarose gel in $0.5 \mathrm{X}$ TBE buffer $(0.045 \mathrm{M}$ Tris-borate and $0.001 \mathrm{M}$ EDTA, PH 8.0) at $50 \mathrm{~V}$ for $90 \mathrm{~min}$. The gels were stained for $15 \mathrm{~min}$ in Ethidium Bromide $(0.5 \mathrm{mg} \mathrm{ml}-1$ BET) and de-stained for $15 \mathrm{~min}$ in distilled water and then photographed under UV light. The sizes of restriction fragments generated were measured directly from the same gels and compared to a standard $(1 \mathrm{~kb})$ Invitrogen-type scale used as a molecular weight marker. PCR products $(30 \mu \mathrm{l}$ volume) of the 36 Phytophthora spp., isolates were sent to Eurofins MWG Operon DNA Sequencing Department (France)

\section{Phylogenetic analyses}

The obtained sequences of the ITS region of Phytophthora spp. isolates were compared with those listed in the GenBank of the National Center for Biotechnology Information (NCBI, http://blast.ncbi.nlm.nih.gov/Blast.cgi) using the option "BLAST search". Similarity rates were determined between the sequences obtained in the course of this study and those present in GenBank database. Sequences were considered similar only when they had a percentage homology of more than $97 \%$.

\section{Pathogenicity of Phytophthora spp isolates. Inoculum preparation of Phytophthora spp, isolates and leaf disks test}

The zoospore suspensions used for artificial inoculation of cocoa tree leaf disks was prepared from Phytophthora cultures contained in Roux flasks with pea agar medium. 5 day old cultures were exposed to a 12-hour photoperiod for 6 days so as to 
induce the formation of sporocysts. Cultures were flooded with $40 \mathrm{ml}$ of sterile distilled water and placed in a refrigerator $\left(4{ }^{\circ} \mathrm{C}\right)$ for 15 minutes. To cause thermal shock, they were exposed to light from an incandescent lamp (60W) for 45 minutes. Such thermal shock enables the release of zoospores by ripe sporocysts. The zoospore suspension thus obtained was counted with a Malassez cell at a concentration of $3 * 10^{5}$ zoospores $\mathrm{ml}^{-1}$. Leaf disks having $15 \mathrm{~mm}$ diameter were arranged in complete randomization in 4 trays (repetition) containing moistened foams of sterile distilled water. Thus, 10 leaf disks per clone and per tray were inoculated for each isolate, that is, 30 washers for the 3 cocoa tree clones (SCA6; PA150 and NA32). For each isolate, leaf disks inoculation was performed using a micropipette (Pipetman) by deposit on abaxial side of the leaf up of $10 \mu \mathrm{l}$ of a suspension calibrated at $3 * 10^{5}$ zoospores $/ \mathrm{ml}$. The trays were tightly sealed and incubated at $26{ }^{\circ} \mathrm{C}$ in darkness for 7 days. After a week of incubation, the reading of symptoms was made according to a foliar sensitivity scale next: 0 (no symptoms), 1 (to penetration points), 2 (points in network), 3 (spots in network), 4 (mottled spot) and 5 (real spot).

\section{Experimental design and statistical analysis}

The leaf test was carried out in laboratory trays. Each series of inoculation was performed in 04 trays and each tray was a repetition. In each tray, 18 Phytophthora spp. isolates were tested. Each Phytophthora spp. isolate was tested on 30 leaf disks from 03 cocoa tree clones (01 sensitive clone; 01 moderately resistant clone and 01 resistant clone) at a rate of 10 leaf disks per clone. In each tray, 10 leaf disks from the same clone were placed on a same row, that is, a total of 54 lines of 10 leaf disks/tray. A random screening was carried out to determine the position of each row of 10 leaf disks in each tray. All the isolates were not tested both in a single series. Two series of inoculations were performed at different times with the introduction in each series of 03 control isolates which would be used to adjust the results obtained during both series of inoculation. The Statistica 7.1 software was used for statistical analysis. The notes of symptoms relating to the aggressiveness of isolates, one week after inoculation were subjected to a two-factor analysis of variance: isolate-clones. The comparison of averages was made by the Newman-Keuils test at $5 \%$ threshold in the event of significant differences.

\section{Results}

Molecular identification of Phytophthora spp. and evaluation of the quantitative component of pathogenicity

The amplification of DNA extracts from the 36 Phytophthora spp isolates with the pair of universal primers ITS1 and ITS4 generated a DNA fragment which approximate size was $900 \mathrm{bp}$ (Figure 1, lane $1)$. This value was confirmed by the calculation of the sum of the different restriction fragments generated by restriction enzymes. The ITS regions of all isolates were digested by restriction enzymes (AluI, MspI, HinfI and PvuII), which indicates that the ITS regions of Phytophthora spp. isolates studied contain recognition sites for such enzymes. In the analysis of restriction patterns, only enzyme HaeIII generated a restriction fragment $(900 \mathrm{bp})$ whose size was equivalent to that of Phytophthora spp amplification profile. The analysis of resulting restriction patterns was used to determine the number and size of fragments generated by each enzyme. Thus, after digestion, enzymes $M s p \mathrm{I}$ and PvuII recognized a single restriction site by generating two restriction fragments which size were respectively estimated at 600; $300 \mathrm{bp}$ and 700; $200 \mathrm{bp}$ (Figure 1). The digestion of ITS regions with enzyme AluI produced three fragments, of which the amount of digested fragments was less than the size of the PCR amplification profile. The nucleotide sequence analysis with the taxonomic browser of the server of the bank "GenBank" enabled to ascertain the affiliation of the isolates of Phytophthora studied. The most similar sequences to such isolates were identified as Phytophthora palmivora (Table 1) with a high rate of similarity $(\geq 97 \%)$.

The leaf disks of 3 clones of cacao trees inoculated with a zoospore suspension of Phytophthora palmivora produced brown spots, typical symptoms of Phytophthora attack. The dispersion of aggressiveness notes of Phytophthora palmivora isolates around the average ranged from 0.90 to 2.88; from 1.08 to 2.91 and from 1.29 to 3.93 respectively in clones SCA6; PA150 and NA32 (Figures 2, 3 and 4).

\section{Discussion}

The molecular identification of Phytophthora spp. confirmed that all 36 isolates were $P$. palmivora. The restriction enzyme experiment showed that all isolates had a 900 bp DNA fragment No variation in length was observed in this region, which means that no significant event (deletion/insertion) has appeared to intervene in the amplified intergenic regions. The size of the DNA profile obtained would correspond to the one expected from Phytophthora palmivora ITS regions as reported by Umaya (25). In the restriction analysis, only the enzyme HaeIII generated a restriction fragment equivalent to the approximate size of the undigested fragment of the ITS regions. This result was corroborated by the works of Ristaino et al. (21); in which the analysis of the restriction pattern revealed by enzyme HaeIII enabled to identify $P$. palmivora among nine other 
Phytophthora species. The restriction enzyme AluI generated fragments whose sum of restriction fragments was lower $(520 ; 170 ; 150 \mathrm{bp})$ than the size of the PCR products fragments $(900 \mathrm{bp})$. This could be attributed to the difficulty in viewing fragments of less than $50 \mathrm{bp}$ or the migration of the fragments of the same size on the gel. The second possible reason could be due to the loss of small fragments during electrophoresis on the gel. Similar results were obtained by Appiah et al. (2). Similar work conducted by Lee and Taylor (12) has enabled the identification of species $P$. capsici, $P$. cinnamomi, $P$. citrophthora, $P$. megakarya and $P$. palmivora by the use of RFLP on the PCR products of ITS regions. These results were confirmed by Cooke et al. (7) and Crawford et al. (8). The restriction patterns generated by the different enzymes showed no polymorphism. This reflects the strong conservation of the nucleotide structure of the ITS regions between populations of this species. Similar results were obtained by Martin and Tooley. (13) in which, the analysis of nuclear DNA by the PCR-RFLP technique showed strong interspecific variation between different species of Phytophthora.

The aggressiveness of Phytopthora palmivora isolates was tested in the laboratory by artificial inoculation of leaf disks. Foliar sensitivity grades showed a significant variation of aggressiveness level of the isolates on the 3 cocoa tree clones. This study showed an spectrum of isolates, ranging from less aggressive which essentially characterized isolates having an aggressiveness grade between 0 and 2 to a moderately aggressive level (grade between 2 and 3); then to a high level of aggressiveness whose average aggressiveness grade varied from 3 to 4 . Such aggressiveness variations were noted among isolates collected in the same plot/locality and different plots/localities. Several authors have established identical rankings of aggressiveness levels between isolates of Phytophthora spp. on leaves and pods detached from cocoa trees (10), (17). The effect of the isolate factor and the interaction isolate $\mathrm{x}$ clone has been studied and the analysis of variance of the average aggressiveness grades recorded on the clones showed a significant difference $(P<0.0001)$ of the isolate factor but not the interaction isolate $\mathrm{x}$ clone $(\mathrm{P}$ $=$ 0.098). This analysis showed that the aggressiveness level of the isolates is a characteristic of their own. Isolates would have therefore kept their level of aggressiveness vis-à-vis the three clones. This result confirms work of Zei (28) who observed a non-significant between the Phytophthora palmivora isolates tried and the cocoa tree clones tested. However, this result is contrary to the works of Nyassé et al. (17), in which an effect isolate x clone although less significant was observed between the Phytophthora megakarya isolates and the cocoa tree clones tested. For these authors, such interaction would be linked to the low number of repetitions performed during his study. The different highly significant aggressiveness profiles have shown that $\mathrm{P}$. palmivora isolates do not have the same aggressiveness level. Some studies have shown a similar variation in the aggressiveness of $P$. palmivora isolates from different geographical origins Surujdeo et al. (22). The development of symptoms depends on the host, the pathogen and the environment. In this study, the cocoa tree clones were grown under similar environmental conditions and the selection of leaves at the same stages of development have helped reduce the influence of leaf age and environmental factors. Moreover, the environment in which the trial was performed (constant temperature at $25^{\circ} \mathrm{C}$ ) reduced the influence of the environment on the aggressiveness of $P$. palmivora strains. These observations have highlighted the genetic nature of isolates aggressiveness. According to Blaha \& Lotodé (4), colonization of host leaf area is characterized by the presence of symptoms, is the result of transmission at differential speed of germ tubes by zoospores through the stomata of leaves. This differential pressure of inoculum might influence the time for onset and development of symptoms Abdelhadi (1). Under the conditions of our trial, the leaf disks were inoculated with deposits of zoospore suspension on the lower surface. This arrangement facilitated the penetration of zoospore germ tubes through the opening of stomata during the infection process. Similar results were obtained by Torto-Alalibo et al. (24) on Phytophthora. pisi and Phytophthora. Sojae. These authors after having inoculated pea roots with a zoospore suspension followed by stereomicroscopic observations confirmed the importance of zoospores as infectious agents of root rot. In addition, the different levels of aggression observed, despite the success of the infection, justify the use of that criterion as a factor expressing the aggressiveness of isolates. The appearance of the symptoms characterizing the disease after deposit of the suspension of zoospores reflects the response of the host tissue to the penetration of the pathogen infectious strands. Indeed, plant pathogens, and especially phytophthora species after the installation phase, generally grow via hyphae by modulating the morphological, biochemical and physiological process by secretion of proteins and other molecules also known as effectors. This analysis is consistent with the different levels of attack observed in all countries where the disease is rife. These results are similar to those obtained by Montarry et al. (14), in the pathosystem $P$. infestans / potato.

\section{Conclusion}

The study of the quantitative component aggressiveness of pathogenicity showed a difference 
of aggressiveness among $P$. palmivora isolates. The number of isolates studied in this trial is certainly not representative of the entire existing population in Côte d'Ivoire. However, this investigation is an evidence of the highly heterogeneous nature of the aggressiveness level of isolates in this population. This heterogeneity is noticed in isolates belonging either to the same plot of land or plots located in different areas. Our results have shown that it is possible to use this criterion to assess the aggressiveness of $P$. palmivora isolates but also to quantify the level of resistance as part of an early breeding program of cocoa tree to the disease.

\section{References}

1. Abdelhadi H. (2003). Caractérisation de populations de phytophthora infestans (mont.) de bary dans la région de Saïs. Thèse de Doctorat de 1'Université Sidi Mohammed Ibn Abdallah, 251p.

2. Appiah A.A, Flood J., Archer A., \& Bridge P.D. (2003). Molecular analysis of the major Phytophthora species on cocoa. Plant Pathol. 53:209-219.

3. Babacauh K.D. (1980). Structure et dynamique des populations de Phytophthora sp. Parasite du cacaoyer (Theobroma cacao L.). Thèse de Doctorat d'Etat. Université de Paris -Sud, centre d'Orsay, 153 p.

4. Blaha G., \& Lotodé R. (1982). Etude comparée du pouvoir pathogène sur semenceaux de Theobroma cacao des espèces de Phytophthora parasites du cacaoyer : analyse des éléments du pouvoir pathogène de Phytophthora palmivora et de $P$. megakarya. Café Cacao Thé, 25 (4): 237-266.

5. Brasier C.M., \& Griffin M.J., (1979). Taxonomy of Phytophthora palmivora on cocoa. Transactions of the British Mycological Society 72, 111-43.

6. Cilas C., Lanaud C., Nyassé S., N'Goran J .A.K. Kebe B.I., Ducamp M., Flamant M. H., Risterucci A.M., Pieretti I., Sounigo O., Thevenin J.M., Despreaux D., 1998. La résistance à la pourriture brune des cabosses due à Phytophthora spp. Recherche des composantes de la résistance. Plantations Recherche Développement, 5 : 441446.

7. Cooke D.E.L., Drenth A., Duncan J.M., Wagels G., \& Brasier C.M. (2000). A molecular phylogeny of Phytophthora and related Oomycetes. Fungal Genetics and Biology 30, 17-32.

8. Crawford, A. R., Bassam B. J., Drenth A., Maclean D. J., \& Irwin J. A. G. (1996). Evolutionary relationships among Phytophthora species deduced from rDNA sequence analysis. Mycol. Res. 100(4):437-443.

9. Flood J. (2006). The threat from global spread of cocoa pests and diseases: hypothetical scenario or clear and present danger. In: Proceedings of the 15th International Cocoa Research Conference. 9-10 October 2006, San Jose (Costa Rica), pp.857-872.

10. Iwaro A.D., Sreenivasan T.N., \& Umaharan P. (1998). Cacao resistance to Phytophthora: effect of pathogen species, inoculation and pod maturity. European Journal of Plant Pathology, 104: 11-15.

11. Kébé B. I., 1999. Rapport Annuel d'Activité 1998, Programme Café- Cacao- Cola, CNRA, Côte d'Ivoire, 39 p.

12. Lee, S. B., \& Taylor J. W. (1992). Phylogeny of five Funguslike Protoctistan Phytophthora species, Inferred from the Internal Transcribed Spacers of Ribosomal DNA. Mol. Biol. Evol. 9(4):636-653.

13. Martin, F. N. and P. W. Tooley. 2004. Identification of Phytophthora isolates to species level using restriction fragment length polymorphism analysis of a polymerase chain reaction amplified region of mitochondrial DNA. Phytopathology, 94: 983-991.

14. Montarry J, Corbiere R, Lesueur S, Glais I. and Andrivon D. (2006). Does selection by resistant hosts triggers local adaptation in plant-pathogen systems. Journal of Evolutionary Biology, 19: 522- 531.

15. N'doumbe-Nkeng M. (1996). Traitement des données épidémiologiques sur la pourriture brune des cabosses du cacaoyer au Cameroun. Rapport de stage en Biométrie, Cirad-cp, Montpellier, France, 145 p.

16. Nyassé S. (1997). Etude de la diversité de Phytophthora megakarya et caractérisation de la résistance du cacaoyer (Theobroma cacao L.) à cet agent pathogène. Thèse de Doctorat, INP Toulouse, $113 \mathrm{p}$.

17. Nyassé S., Cilas C., Herail C., \& Blaha G. (1995). Leaf inoculation as an early screening test for cocoa (Theobroma cacao L.) resistance to Phytophthora black pod disease. Crop Protection, 14 (8): $657-663$.

18. Nyassé, S., D. Despréaux \& Cilas C. (2002). Validity of a leaf inoculation test to assess the resistance to Phytophthora megakarya in cocoa (Theobroma cacao L.) diallel mating design. Euphytica, 123: 395-399.

19. Ortiz-Garcia C.F. (1996). Etude de la diversité génétique de populations de Phytophthora pathogens du cacaoyer (Theobroma cacao L.) et du cocotier (Cocos nucefera L). Thèse de Doctorat de l'université Paul Sabatier, $85 \mathrm{p}$.

20. Ploetz R. (2016). The impact of diseases on cacao production: a global overview, in Cacao Diseases: A History of Old Enemies and New Encounters, eds Bailey P. A., Meinhardt L. W., editors. (New York, NY: Springer International Publishing;), 33-59.

21. Ristaino JB, Madritch M, Truot CL, Parra G, (1998). PCR amplification of ribosomal DNA for species identification in the plant pathogen genus Phytophthora. Applied and Environmental Microbiology, 64: 948- 954.

22. Surujdeo-Maharaj S., Umaharan P., \& Iwaro A.D. (2000). A study of genotype isolate interaction in cacao (Theobroma cacao L.): resistance of cacao genotype to isolates of Phytopthora palmivora. Euphytica, 118 : 295-303.

23. Tahi G. M., Kébé B. I., Sangare A., Mondeil F., Cilas C. and Eskes A. B. (2006). Foliar resistance of cacao (Theobroma cacao) to Phytophthora palmivora as an indicator of pod resistance in the field: interaction of cacao genotype, leaf age and duration of incubation. Plant Pathology 55, 776-782.

24. Torto,T., Li, S., Styer, A., Huitema, E., Testa, A., A. R. Gow, N., P. West, P. \& Kamoun,S. (2007). EST mining and functional expression assays identity extracellular effector proteins from the plant pathogen Phytophthora. Genome Research 13; 1675- 1685.

25. Umaya A. 2004. Keragaman Genetik P. palmivora pada Kakao di Indonesia Berdasarkan Pendekatan Molekuler. Disertasi. Sekolah Pascasarjana IPB. Bogor. Menara Perkebunan, 74(2), 75-85.

26. Van der Vossen H. A. M., (1997). Strategies of variety improvement in cocoa with emphasis on durable disease resistance. In: Proceedings, International Workshop on the contribution of disease resistance to cocoa variety improvement, Salvador, Bahia, Brazil, pp: 27-31.

27. White, T.J., T. Bruns, Lee S. \& Taylor J.W. (1990). Amplification and direct sequencing of fungal ribosomal RNA genes for phylogenetics. In Innis, M.A., D.H. Gelfand, J.J. Sninsky \& T.J. White (eds.) PCR Protocol: A Guide to Methods and Applications. New York, Academic Press. p. 315-322.

28. Zéi P. (2002). Evaluation de la résistance du cacaoyer (Theobroma cacao L.) à Phytophthora sp, agent de la pourriture brune des cabosses: Etude de la spécificité parasitaire et des corrélations test feuilles - test cabosses. Mémoire de fin d'année pour l'obtention du Diplôme d'Agronomie Approfondie (DAA), INPHB, Yamoussoukro.62 


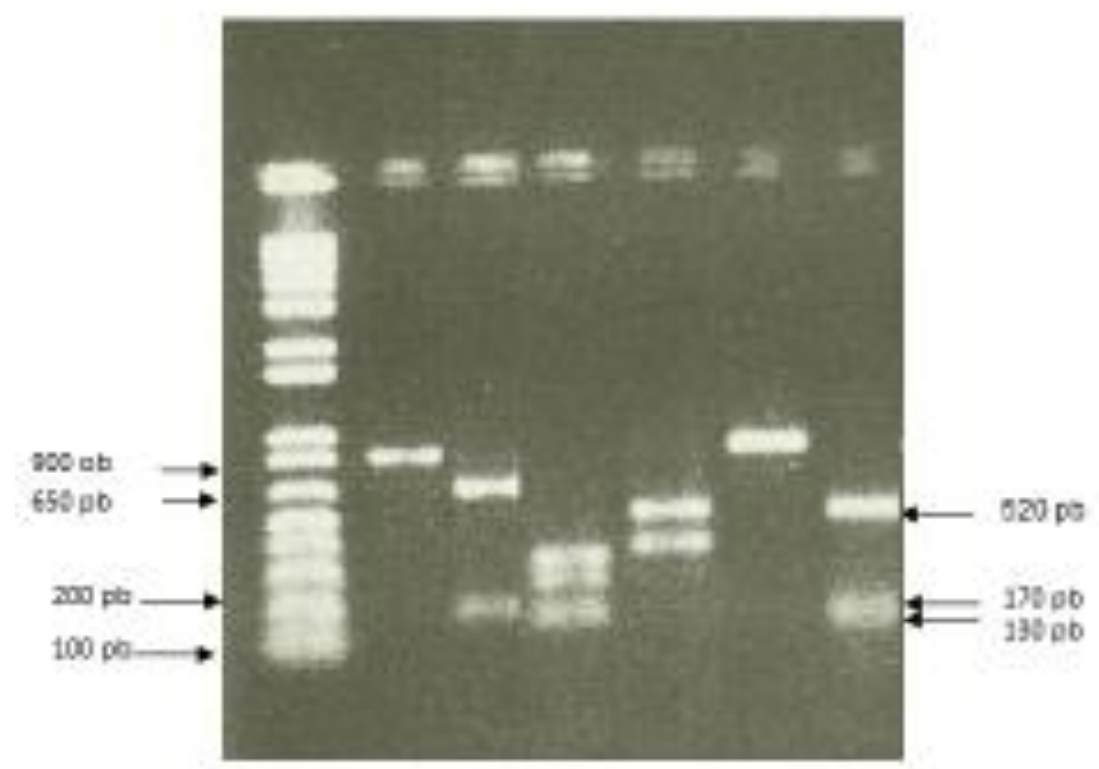

Figure 1: PCR-RFLP profiles of Phytophthora spp. isolates after digestion with restriction enzymes. M: Molecular marker 1 kb (Invitrogen); Undigested DNA (1); PvuII (2), HinfI (3), MspI (4), HaeIII (5); AluI (6).

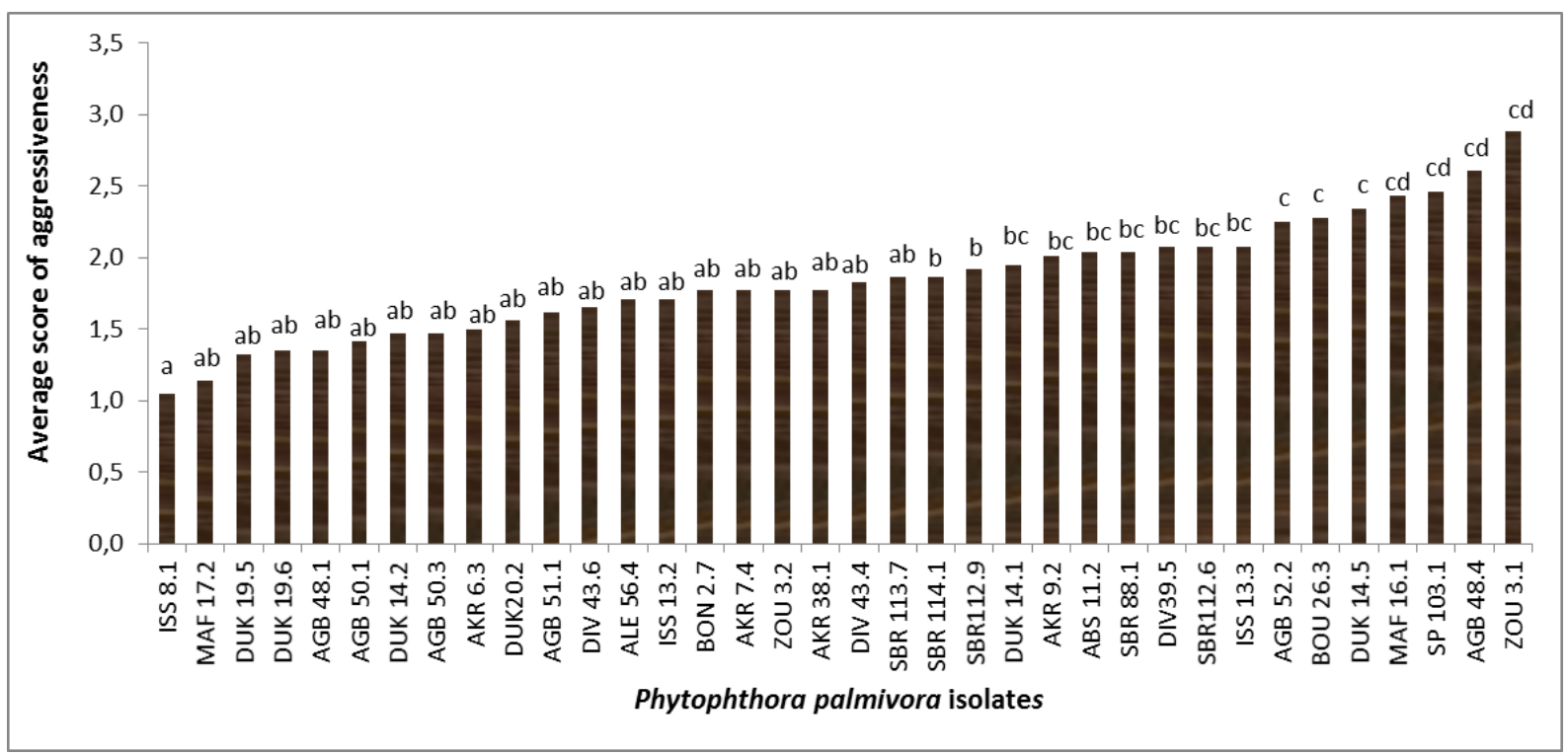

Figure 2: Foliar sensitivity of cocoa tree clone SCA 6 with regard to Phytophthora palmivora isolates.

The bars followed by the same letter are not significantly different according to the Newman and Keuls test at $5 \%$ threshold. 


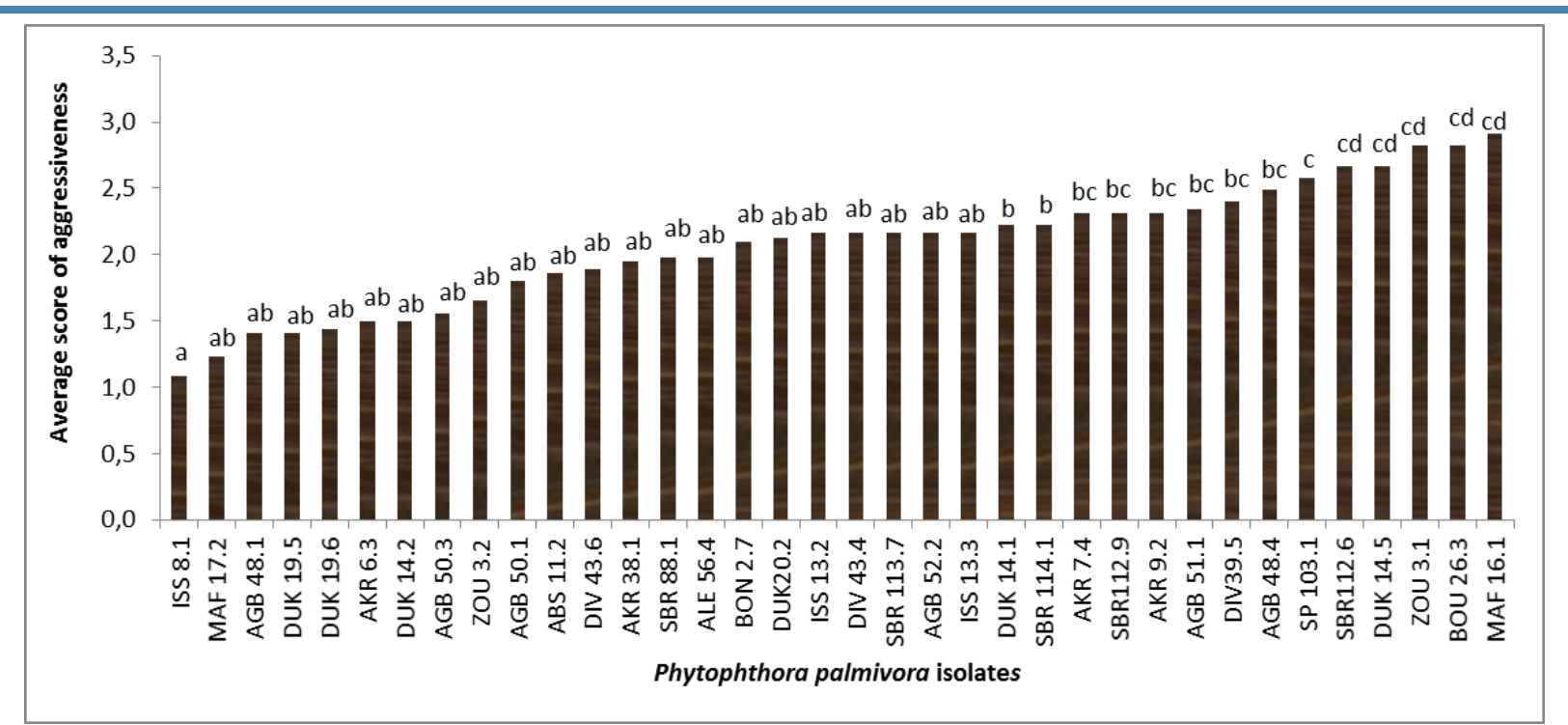

Figure 3: Foliar sensitivity of cocoa tree clone PA150 with regard to Phytophthora palmivora isolates

The bars followed by the same letter are not significantly different according to the Newman and Keuls test at $5 \%$ threshold.

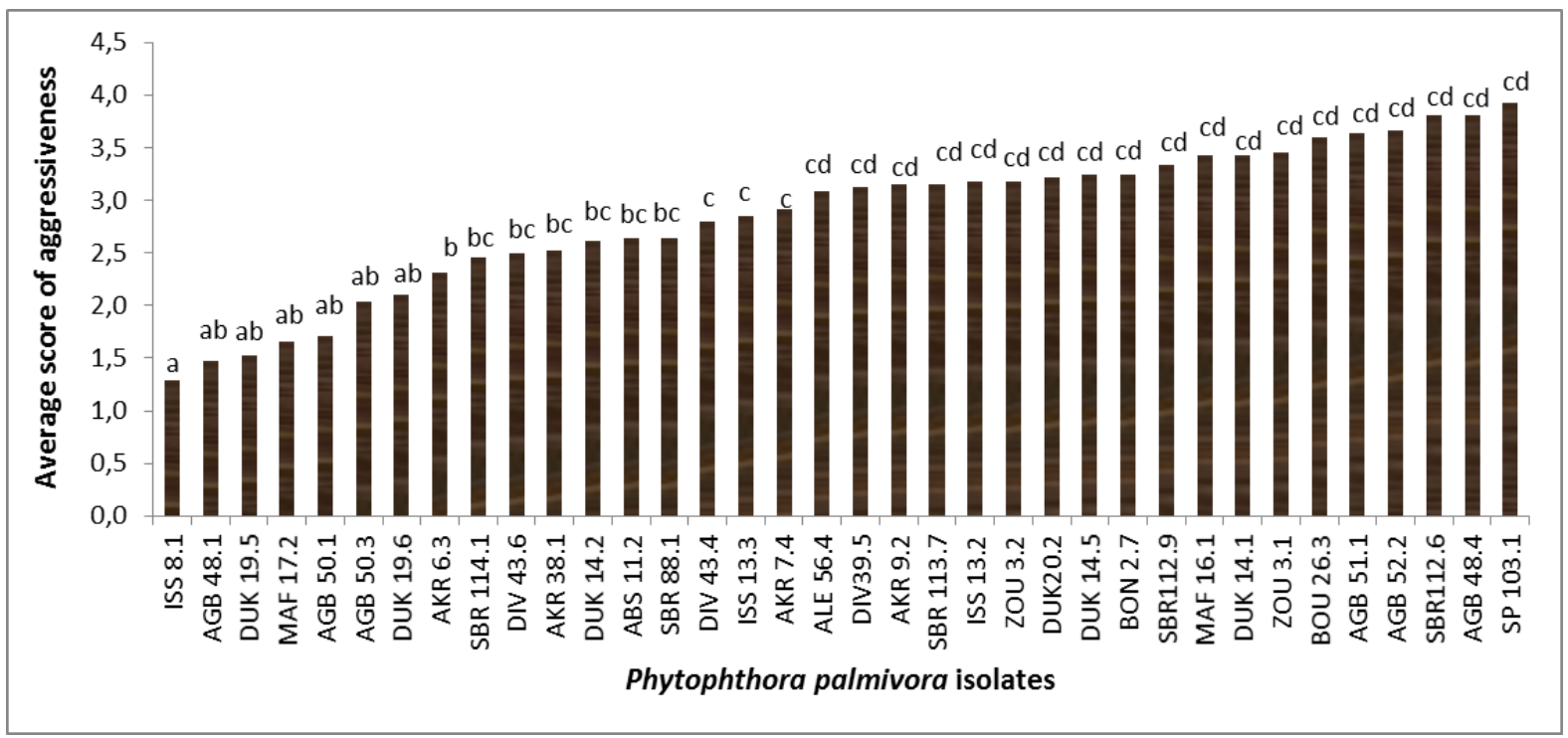

Figure 4: Foliar sensitivity of cocoa tree clone NA32 with regard to Phytophthora palmivora isolates.

The bars followed by the same letter are not significantly different according to the Newman and Keuls test at $5 \%$ threshold. 
Molecular Identification of Phytophthora palmivora in the Cocoa Tree Orchard of Côte d'Ivoire and Assessment of the Quantitative Component of Pathogenicity

Table 1: DNA sequences of Phytophthora palmivora in cocoa tree orchard

\begin{tabular}{|c|c|c|c|}
\hline Species. & Codes & Geographical Origin & Acc.No. GenBank \\
\hline Phytophthora palmivora & Seq1 & San-pédro & KJ144771 \\
\hline Phytophthora palmivora & Seq2 & Soubré & KJ144772 \\
\hline Phytophthora palmivora & Seq3 & Duékoué & KJ144773 \\
\hline Phytophthora palmivora & Seq4 & Duékoué & KJ144774 \\
\hline Phytophthora palmivora & Seq5 & Divo & KJ144775 \\
\hline Phytophthora palmivora & Seq6 & Maféré & KJ144776 \\
\hline Phytophthora palmivora & Seq7 & Niablé & KJ144777 \\
\hline Phytophthora palmivora & Seq8 & Divo & KJ144778 \\
\hline Phytophthora palmivora & Seq9 & San-pédro & KJ144779 \\
\hline Phytophthora palmivora & Seq10 & Duékoué & KJ144780 \\
\hline Phytophthora palmivora & Seq11 & Divo & KJ144781 \\
\hline Phytophthora palmivora & Seq12 & Soubré & KJ144782 \\
\hline Phytophthora palmivora & Seq13 & Maféré & KJ144783 \\
\hline Phytophthora palmivora & Seq14 & Niablé & KJ144784 \\
\hline Phytophthora palmivora & Seq15 & Duékoué & KJ144785 \\
\hline Phytophthora palmivora & Seq16 & Issia & KJ144786 \\
\hline Phytophthora palmivora & Seq17 & Divo & KJ144787 \\
\hline Phytophthora palmivora & Seq18 & Maféré & KJ144788 \\
\hline Phytophthora palmivora & Seq19 & Soubré & KJ144789 \\
\hline Phytophthora palmivora & Seq20 & Zoukougbeu & KJ144790 \\
\hline Phytophthora palmivora & Seq21 & Saioua & KJ144791 \\
\hline Phytophthora palmivora & Seq22 & Divo & KJ144792 \\
\hline Phytophthora palmivora & Seq23 & Zoukougbeu & KJ144793 \\
\hline Phytophthora palmivora & Seq24 & Bonoua & KJ144794 \\
\hline Phytophthora palmivora & Seq25 & Duékoué & KJ144795 \\
\hline Phytophthora palmivora & Seq26 & San-pédro & KJ144796 \\
\hline Phytophthora palmivora & Seq27 & Saioua & KJ144797 \\
\hline Phytophthora palmivora & Seq28 & Issia & KJ144798 \\
\hline Phytophthora palmivora & Seq29 & Issia & KJ144799 \\
\hline Phytophthora palmivora & Seq30 & Bonoua & KJ144800 \\
\hline Phytophthora palmivora & Seq31 & Alépé & KJ144801 \\
\hline Phytophthora palmivora & Seq32 & Saioua & KJ144802 \\
\hline Phytophthora palmivora & Seq33 & Bonoua & KJ144803 \\
\hline Phytophthora palmivora & Seq34 & Soubré & KJ144804 \\
\hline Phytophthora palmivora & Seq35 & Alépé & KJ144805 \\
\hline Phytophthora palmivora & Seq36 & Zoukougbeu & KJ144806 \\
\hline
\end{tabular}

